\title{
OPTIMASI FORMULASI FLAKES BERBASIS TEPUNG UBI CILEMBU TEPUNG TAPIOKA SERTA TEPUNG KACANG HIJAU

\author{
Thomas Gozali
} \\ Ela Turmala Sutrisno \\ Nur Maryam Saleha
}

\begin{abstract}
Program Studi Teknologi Pangan, Fakultas Teknik, Universitas Pasundan, J1. Dr.Setiabudi No 193, Bandung, 40153, Indonesia
\end{abstract}

E-mail : thomasgozali@gmail.com

\begin{abstract}
The purpose this research is to determine the best formulation of Flakes have as a base Cilembu sweet potato flour, tapioca flour,and green bean flour making using the Design Expert Application with Design D-optimal method. This research was done within two phases. The preliminary phase is was to determine starch and carotenoid in Cilembu sweet potato flour. The main this research is determine the best formulation of Flakes The respon in this research are chemical responses (including protein content, fat content, fyber content, and water content), physical response (including water absorption, and wrecked time), and sensory response (including color, aroma, flavor, and texture). The Flakes is made from Cilembu sweet potato flour, tapioca flour,and green bean flour. The application provides 11 formulations and made 1 formulations optimal, which Cilembu sweet potato flour 27,73\%, tapioca flour 14,99\%, and green bean flour $12,29 \%$, sugar $14 \%$, salt $1 \%$, and water $30 \%$. The responses results are $8,87 \%$ for protein content, $0,38 \%$ for fat content, $3,96 \%$ for crude fyber contect, $3,5 \%$ for water content, $141,03 \%$ for water absorption, 15 minutes wrecked time, 4,7 for color attribute before add milk, 5,33 for color attribute after add milk, 5,47 for flavor attribute after add milk, 5,27 for aroma attribute after add milk, 4,57 for flavor texture after add milk.
\end{abstract}

Keyword: Flakes, Cilembu sweet potato flour, Optimation

\section{Pendahuluan}

Ubi Jalar (Ipomea batatas L.) memiliki sumber karbohidrat utama setelah padi, jagung dan ubi kayu, serta mempunyai peranan penting dalam penyediaan bahan pangan pangan, serta bahan baku industri. Diantara semua bahan pangan sumber karbohidrat terutama padi, singkong dan jagung, ubi jalar terbukti memiliki keunggulan dan keuntungan yang sangat tinggi bagi masyarakat Indonesia dari segi produktivitas dan karbohidrat yang tinggi, varietasnya yang beragam, harga yang relatif lebih murah dan telah dikenal secara turun temurun oleh masyarakat Indonesia (Wijayanti dkk, 2015).

Ubi jalar (Ipomoea batatas L.) merupakan tanaman palawija termasuk family Convulvulaceae yang tumbuh menjalar dan menghasilkan umbi dari akar yang membesar (Aryanti, 2012).

Di Indonesia terdapat sekitar 1000 jenis ubi jalar dan salah satu jenis ubi jalar yang paling populer adalah ubi jalar asal Desa Cilembu di Kecamatan Pamulihan, Kabupaten Sumedang Jawa Barat (Pratiwi, 2016).

Badan Pusat Statistik (2015) mencatat bahwa produksi ubi jalar menurut provinsi di Indonesia khususnya Jawa Barat pada tahun 2011 sampai 2015 masingmasing yaitu 429.372 ton; 436.577 ton; 485.065 ton; 471.737 ton; 456.176 ton. Bedarasakan luas panen Jawa Barat berada pada urutan pertama pada tahun 2011 sampai tahun 2015, yakni berturut berturut 27.931 ha; 26.531 ha; 26.635 ha; 25.641 ha; dan 23.514 ha. Bedasarkan produktivitas ubi jalar di Jawa Barat pada tahun 2011-2015 yakni berturut-turut 153,72 Ku/Ha;
164,55 Ku/Ha; $182,12 \mathrm{Ku} / \mathrm{Ha} ; 183,98 \mathrm{Ku} / \mathrm{Ha} ;$ dan 194,00 Ku/Ha.

Selama ini konsumsi masyarakat Indonesia terhadap ubi cilembu hanya terbatas dengan cara diolah menjadi produk olahan tradisional dalam bentuk camilan atau jajanan pasar, seperti ubi Cilembu rebus, goreng, bakar, keripik, dan jenis olahan lainnya.

Untuk lebih memanfaatkan ubi Cilembu dapat ditempuh dengan mengolahnya menjadi tepung dan bermanfaat sebagai bahan substitusi tepung terigu yang dapat diolah menjadi beberapa produk pangan (Ketra dkk, 2015). Tepung merupakan bentuk produk olahan setengah jadi yang bermanfaat untuk mempermudah penyimpanan dan mempertahankan kualitas (Aryanti, 2012).

Tepung ubi jalar memiliki kandungan karbohidrat yang tinggi sehingga baik digunakan untuk menghasilkan aneka produk pangan yang mempunyai nilai gizi (Ketra dkk, 2015). Sehingga dengan kandungan gizinya, tepung ubi jalar ini dapat digunakan dalam proses pembuatan Flakes.

Kacang hijau (Vigna radiate) merupakan tanaman palawija yang banyak ditanam oleh petani di Indonesia setelah padi, jagung, kedelai dan kacang tanah (Kurniawati dkk, 2013).

Kacang hijau mempunyai peranan penting dalam menunjang peningkatan gizi makanan rakyat. Penggunaan kacang hijau juga sangat beragam, dari olahan sederhana hingga produk olahan canggih (Zebua $\mathrm{dkk}, 2012)$. 
Badan Pusat Statistik Nasional (2015) mencatat bahwa produksi kacang hijau menurut provinsi di Indonesia khususnya Jawa Barat pada tahun 2011 sampai 2015 masing-masing yaitu 14.221 ton; 10.198 ton; 11.002 ton; 12.749 ton; 9.691 ton.Berdasarkan luas panen kacang hijau di Jawa Barat tahun 2011-2015 berturut-turut yaitu 12.507 ha; 9.001 ha; 9.121 ha; 10.228 ha; dan 7.607 ha. Berdasarkan produktivitas kacang hijau di Jawa Barat tahun 2011-2015 berturutturut yaitu $11,37 \mathrm{Ku} / \mathrm{Ha} ; 11,32 \mathrm{Ku} / \mathrm{Ha} ; 12,06 \mathrm{Ku} / \mathrm{Ha}$; 12,46 Ku/Ha12,74 Ku/Ha.

Perubahan zaman ikut mengubah perilaku dan kebiasaan makan, terutama dalam hal sarapan. Waktu penyiapan yang semakin singkat mengharuskan adanya menu sarapan yang dapat disajikan secara cepat (Sianturi dkk, 2014).

Sarapan penting untuk memenuhi asupan gizi yang dibutuhkan untuk menjalani aktivitas sehari-hari. Sarapan pagi yang dikonsumsi masyarakat dewasa ini masih terbatas makanan yang terbuat dari sereal seperti beras, jagung dan gandum sedangkan ubi jalar sendiri masih jarang sekali dimanfaatkan sebagai bahan utama pembuatan sereal. Permintaan konsumen akan sarapan sekarang ini bergeser menjadi suatu produk sarapan yang praktis, cepat saji serta bergizi. Oleh karena itu, penting diciptakannya suatu produk sereal yang memenuhi kriteria sebagai pangan alternatif yang kaya akan energi, protein dan zat gizi lain (Wijayanti dkk, 2015).

Flakes dapat dibuat dari berbagai macam bahan makanan yang mengandung karbohidrat dan dapat ditambahkan bahan makanan sumber zat gizi lain untuk memenuhi kebutuhan gizi (Gisca I.D dkk, 2013). Oleh karena itu salah satu bahan makanan yang dapat menajdi sumber energi dan protein adalah ubi Cilembu dan kacang hijau.

Program linier adalah suatu cara yang dapat digunakan untuk memecahkan permasalahan yang berhubungan dengan optimasi linier (nilai maksimum atau nilai minimum). Aplikasi program linier yang digunakan adalah Design Expert 7.0. Program ini dapat digunakan untuk menyelesaikan masalah yang berhubungan dengan optimalisasi.

Pengembangan formulasi menjadi hal yang sangat penting sehingga dapat menghasilkan produk pangan yang dapat diterima oleh masyarakat. Pencampuran bahan-bahan dalam formulasi akan mempengaruhi karakteristik mi kering produk yang dihasilkan. Optimalisasi formulasi adalah penentuan formulasi optimal berdasarkan respon yang diteliti.Optimasi dapat juga dijelaskan sebagai suatu kumpulan formula matematis dan metode numerik untuk menemukan dan mengidentifikasikan kandidat terbaik (Sahid, 2015).

\section{Metode Penelitian}

Bahan baku utama yang digunakan dalam penelitian ini adalah ubi jalar varietas Cilembu yang diperoleh langsung dari Desa Cilembu, Kecamatan Pamulihan, Kabupaten Sumedang, Jawa Barat yang kemudian dilakukan proses penepungan, tepung tapioka dengan menggunakan produk dari Rose Brand, dan tepung kacang hijau varietas vima, sedangkan bahan penunjang yang digunakan adalah $\mathrm{Na}$ bisulfit, gula, garam dan air.

Bahan yang digunakan untuk analisis kimia adalah larutan Luff Schoorl, Kalium Iodida (KI), Natrium tiosulfat (Na2S2O3), larutan amilum, nbutanol, $\mathrm{HgO}$, batu didih, larutan I2, Asam Sulfat (H2SO4), aquadest, phenolptalein, Asam Klorida ( $\mathrm{HCl})$, $\mathrm{NaOH}$, Kloroform $(\mathrm{CHCl} 3)$, alkohol, N-heksan.

Alat yang digunakan dalam pembuatan Flakes adalah pengering kabinet, blender, ayakan 80 mesh, timbangan digital, plastik, sendok, spatula, baskom plastik, noodle maker, pisau, loyang, pengukus dan oven.

Alat yang digunakan untuk analisis kimia adalah neraca analitis, pipet tetes, labu Erlenmeyer, labu ukur, buret, batang pengaduk, gelas ukur, dan lain-lain.

Penelitian dibagi menjadi 2 tahapan meliputi penelitian pendahuluan dan penelitian utama. Penelitian pendahuluan yaitu pembuatan tepung ubi Cilembu, dan tepung kacang hijau. Kemudian tepung ubi Cilembu dilakukan analisis kadar karbohidrat (pati) metode Luff Schoorl dan analisis kadar karoten metode spektrofotometri, hal ini dilakukan untuk mengetahui karakteristik bahan baku (tepung ubi Cilembu) yang dapat digunakan sebagai makanan fungsional. Penelitian utama bertujuan untuk menentukan bahan yang akan diformulasikan pada Design Expert metode Mixture Design sebagai bahan yang menjadi variabel tetap dan bahan yang menjadi variabel berubah. Bahan-bahan yang digunakan yaitu : tepung ubi Cilembu, tepung tapioka, tepung kacang hijau, gula pasir, garam, air. Dengan respon yang akan digunakan antara lain uji organoleptik, kadar serat kasar, kadar protein, kadar lemak, kadar air, daya serap air, serta waktu hancur.

Bahan baku utama yang ditambahkan merupakan variabel berubah pada mixture component yaitu tepung ubi Cilembu, tepung tapioka, dan tepung kacang hijau dengan jumlah total variabel berubah $55 \%$ (persen) dari bahan keseluruhan yang dilihat dari sisa jumlah variabel tetap.

Tabel 1. Bahan Tambahan (Variabel Tetap) Dalam Jumlah \%

\begin{tabular}{|c|l|c|}
\hline No & Nama Bahan & Jumlah (\%) \\
\hline 1. & Gula & 14 \\
\hline 2. & Garam & 1 \\
\hline 3. & Air & 30 \\
\hline \multicolumn{2}{|c|}{ Total } & 45 \\
\hline$\quad$ Variabel Berubah & 55 \\
\hline \multicolumn{2}{|c|}{ Total Keseluruhan } & 100 \\
\hline
\end{tabular}


Tabel 2. Variabel Berubah

\begin{tabular}{|c|c|c|c|}
\hline No & Nama Bahan & Low & High \\
\hline 1 & $\begin{array}{ll}\text { Tepung } & \text { Ubi } \\
\text { Cilembu } & \end{array}$ & 20 & 30 \\
\hline 2 & Tepung Tapioka & 10 & 20 \\
\hline 3 & $\begin{array}{l}\text { Tepung Kacang } \\
\text { Hijau }\end{array}$ & 5 & 15 \\
\hline
\end{tabular}

Variabel berubah terdiri dari 3 bahan.Batasanbatasan Flakes yang akan digunakan sebagai bahan baku berupa tepung ubi Cilembu, tepung tapioka, dan tepung kacang hijauditambahkan pada kolom Low dan High.

Berdasarkan hasil dari perhitungan formulasi dengan menggunakan program Design Expert metode mixture design D-optimal pada Flakes ubi Cilembu didapatkan 11 formulasi yang terdiri dari bahan baku (tepung ubi Cilembu, tepung tapioka, dan tepung kacang hijau) dan bahan tambahan (gula, garam, serta air). Kemudian dilakukan pengolahan data hasil analisis berdasarkan respon kadar protein, lemak, serat kasar, kadar air, kadar pati untuk produk dengan formulasi optimal, daya serap air, waktu hancur, warna sebelum perendaman susu, warna, rasa, aroma, dan kerenyahan sehingga akan didapatkan formulasi optimal berdasarkan respon menurut program tersebut terhadap Flakes ubi Cilembu.

Pembuatan tepung ubi Cilembu terdiri dari beberapa proses diantaranya: pencucian, curing, trimming, pengecilan ukuran, perendaman, penirisan, pengeringan, penghancuran, pengayakan. Pembuatan tepung kacang hijau terdiri dari beberapa proses diantaranya: pencucian, penirisan, blansing, pengupasan, pengeringan, penghancuran, pengayakan. Untuk proses pembuatan Flakes diantaranya: pencampuran, pemipihan, pencetakkan, pengukusan, pemanggangan.

\section{Hasil dan Pembahasan \\ Hasil Penelitian Pendahuluan}

\section{Kadar Pati}

Analisis bahan baku tepung ubi Cilembu dilakukan untuk mengetahui kadar pati, analisis ini dilakukan dengan metode Luff Schoorl. Hasil analisis kadar pati menunjukkan bahwa tepung ubi Cilembu tersebut memiliki kadar pati sebesar $83,475 \%$.

\section{Karoten}

Analisis bahan baku tepung ubi Cilembu dilakukan untuk mengetahui kadar karoten, analisis ini dilakukan dengan metode spektrofotometri. Hasil analisis kadar karoten menunjukkan bahwa tepung ubi Cilembu tersebut memiliki kadar karoten sebesar 116,76 ppm.

\section{Hasil Penelitian Utama}

\section{Kadar Protein}

Hasil analisis sidik ragam atau uji anova menunjukkan formula yang dibuat berpengaruh nyata (probabilitas $<0,05$ ) terhadap kadar protein yang diuji dengan selang kepercayaan 95\%. Analisis sidik ragam yang dilakukan oleh program Design Expert metode Mixture design d-optimal pada nilai respon kimia kadar protein terhadap formula yang dibuat, menunjukkan model yang dibuat adalah signifikan (probabilitas < 0,05 ), pada selang kepercayaan $95 \%$ dengan nilai $\mathrm{p}=$ 0,0010 . Artinya formula yang dibuat berpengaruh nyata terhadap respon kadar protein, sehingga nilai respon tersebut dapat digunakan untuk proses optimasi yaitu untuk mendapatkan produk dengan karakteristik yang optimum.

Grafik di bawah menunjukkan formulasi optimal berdasarkan respon kadar protein yang diprediksi oleh grafik ini sebesar 9,95\% dimana batas bawah kadar protein dari keseluruhan formulasi yaitu 4,29\% dan batas atas sebesar $14,71 \%$. Untuk mencapai nilai kadar protein sesuai dengan yang diprediksikan oleh program pada pengaplikasian produk Flakes harus menggunakan Tepung Ubi Cilembu 27,73\% Tepung Tapioka 14,99\%, dan $12,29 \%$ Tepung Kacang Hijau.

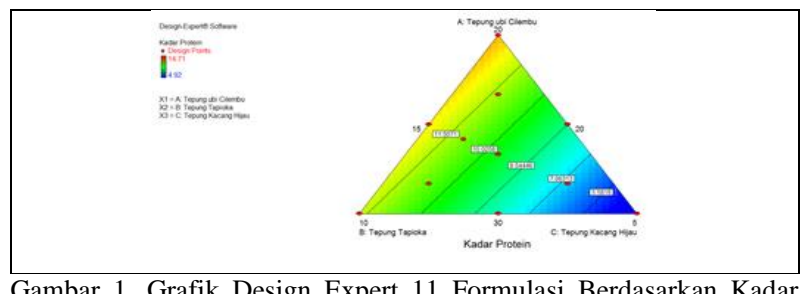
Protein

\section{Kadar Lemak}

Hasil analisis sidik ragam atau uji anova menunjukkan formula yang dibuat berpengaruh nyata (probabilitas < 0.05) terhadap kadar lemak yang diuji dengan selang kepercayaan 95\%. Analisis sidik ragam yang dilakukan oleh program Design Expert metode Mixture design d-optimal pada nilai respon kimia kadar lemak terhadap formula yang dibuat, menunjukkan model yang dibuat adalah signifikan (probabilitas < 0.05 ), pada selang kepercayaan $95 \%$ dengan nilai $\mathrm{p}=$ 0,0081 . Artinya formula yang dibuat berpengaruh nyata terhadap respon kadar lemak, sehingga nilai respon tersebut dapat digunakan untuk proses optimasi yaitu untuk mendapatkan produk dengan karakteristik yang optimum.

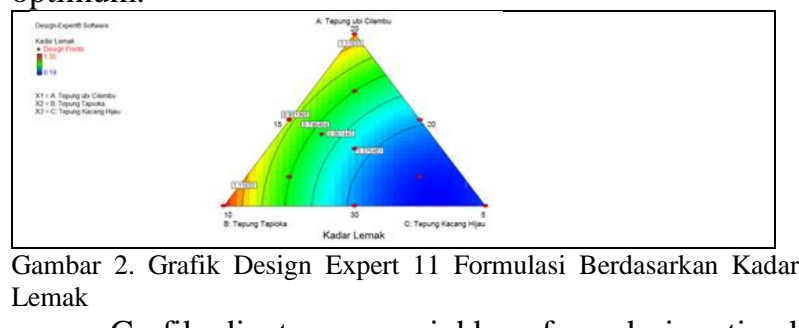

Grafik di atas menunjukkan formulasi optimal berdasarkan respon kadar lemak yang diprediksi oleh grafik ini sebesar 0,55\% dimana batas bawah kadar protein dari keseluruhan formulasi yaitu $0,19 \%$ dan batas atas sebesar $1,35 \%$. Untuk mencapai nilai kadar lemak sesuai dengan yang diprediksikan oleh program 
pada pengaplikasian produk Flakes harus menggunakan Tepung Ubi Cilembu 27,73\% Tepung Tapioka 14,99\%, dan 12,29\% Tepung Kacang Hijau.

\section{Kadar Serat Kasar}

Hasil analisis sidik ragam atau uji anova menunjukkan formula yang dibuat berpengaruh nyata (probabilitas < 0.05) terhadap kadar serat kasar yang diuji dengan selang kepercayaan 95\%. Analisis sidik ragam yang dilakukan oleh program Design Expert metode Mixture design d-optimal pada nilai respon kimia kadar serat kasar terhadap formula yang dibuat, menunjukkan model yang dibuat adalah signifikan (probabilitas < 0.05), pada selang kepercayaan 95\% dengan nilai $\mathrm{p}=0,0003$. Artinya formula yang dibuat berpengaruh nyata terhadap respon kadar serat kasar, sehingga nilai respon tersebut dapat digunakan untuk proses optimasi yaitu untuk mendapatkan produk dengan karakteristik yang optimum.

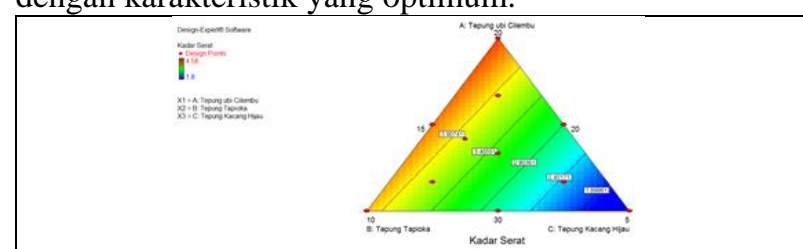

Gambar 3. Grafik Design Expert 11 Formulasi Berdasarkan Kadar Serat Kasar

Grafik di atas menunjukkan formulasi optimal berdasarkan respon kadar serat kasar yang diprediksi oleh grafik ini sebesar 3,42\% dimana batas bawah kadar serat kasar dari keseluruhan formulasi yaitu 1,8\% dan batas atas sebesar $4,58 \%$. Untuk mencapai nilai kadar serat kasar sesuai dengan yang diprediksikan oleh program pada pengaplikasian produk Flakes harus menggunakan Tepung Ubi Cilembu 27,73\% Tepung Tapioka 14,99\%, dan 12,29\% Tepung Kacang Hijau.

\section{Kadar Air}

Hasil analisis sidik ragam atau uji anova menunjukkan formula yang dibuat tidak berpengaruh nyata (probabilitas $>0.05$ ) terhadap kadar air yang diuji dengan selang kepercayaan $95 \%$. Analisis sidik ragam yang dilakukan oleh program Design Expert metode Mixture design d-optimal pada nilai respon kimia kadar air terhadap formula yang dibuat, menunjukkan model yang dibuat adalah tidak signifikan (probabilitas > 0.05 ), pada selang kepercayaan $95 \%$ dengan nilai $\mathrm{p}=$ 0,0605 . Artinya formula yang dibuat tidak berpengaruh nyata terhadap respon kadar air, sehingga nilai respon tersebut tidak dapat digunakan untuk proses optimasi yaitu untuk mendapatkan produk dengan karakteristik yang optimum.

Grafik di bawah menunjukkan formulasi optimal berdasarkan respon kadar air yang diprediksi oleh grafik ini sebesar 3,84\% dimana batas bawah kadar air dari keseluruhan formulasi yaitu $2,19 \%$ dan batas atas sebesar 4,52\%. Untuk mencapai nilai kadar air sesuai dengan yang diprediksikan oleh program pada pengaplikasian produk Flakes harus menggunakan
Tepung Ubi Cilembu 27,73\% Tepung Tapioka 14,99\%, dan 12,29\% Tepung Kacang Hijau.

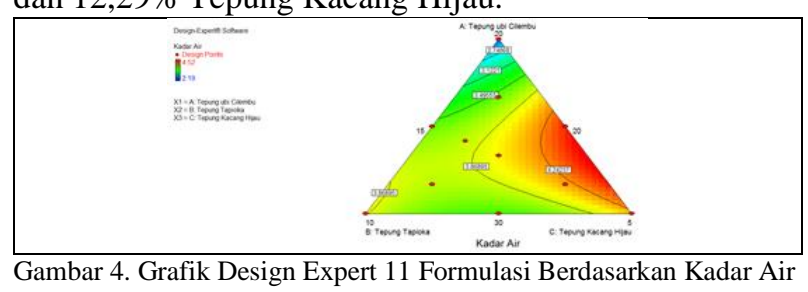

\section{Kadar Pati}

Hasil penelitian menunjukan bahwa kadar pati pada formulasi terpilih menghasilkan kadar pati sebesar $77,29 \%$.

\section{Daya Serap Air}

Hasil analisis sidik ragam atau uji anova menunjukkan formula yang dibuat berpengaruh nyata (probabilitas $<0.05$ ) terhadap daya serap air yang diuji dengan selang kepercayaan 95\%. Analisis sidik ragam yang dilakukan oleh program Design Expert metode Mixture design d-optimal pada nilai respon fisik daya serap air terhadap formula yang dibuat, menunjukkan model yang dibuat adalah signifikan (probabilitas < 0.05 ), pada selang kepercayaan $95 \%$ dengan nilai $\mathrm{p}=$ 0,0001 . Artinya formula yang dibuat berpengaruh nyata terhadap respon daya serap air, sehingga nilai respon tersebut dapat digunakan untuk proses optimasi yaitu untuk mendapatkan produk dengan karakteristik yang optimum.

Grafik di bawah menunjukkan formulasi optimal berdasarkan respon daya serap air yang diprediksi oleh grafik ini sebesar 147,08\% dimana batas bawah daya serap air dari keseluruhan formulasi yaitu $134,91 \%$ dan batas atas sebesar $153,27 \%$. Untuk mencapai nilai daya serap air sesuai dengan yang diprediksikan oleh program pada pengaplikasian produk Flakes harus menggunakan Tepung Ubi Cilembu 27,73\% Tepung Tapioka 14,99\%, dan 12,29\% Tepung Kacang Hijau.

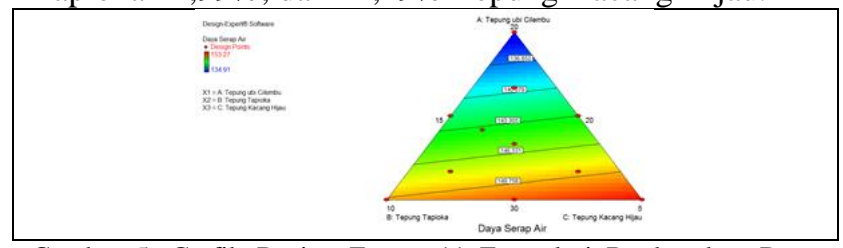

Gambar 5. Grafik Design Expert 11 Formulasi Berdasarkan Daya Serap Air

\section{Waktu Hancur}

Hasil analisis sidik ragam atau uji anova menunjukkan formula yang dibuat berpengaruh nyata (probabilitas < 0.05) terhadap waktu hancur yang diuji dengan selang kepercayaan 95\%. Analisis sidik ragam yang dilakukan oleh program Design Expert metode Mixture design d-optimal pada nilai respon fisik waktu hancur terhadap formula yang dibuat, menunjukkan model yang dibuat adalah signifikan (probabilitas < 0.05), pada selang kepercayaan $95 \%$ dengan nilai $\mathrm{p}=$ 0,0336 . Artinya formula yang dibuat berpengaruh nyata terhadap respon uji waktu hancur, sehingga nilai respon 
tersebut dapat digunakan untuk proses optimasi yaitu untuk mendapatkan produk dengan karakteristik yang optimum.

Grafik di bawah menunjukkan formulasi optimal berdasarkan respon waktu hancur yang diprediksi oleh grafik ini sebesar 14,23 menit dimana batas bawah waktu hancur air dari keseluruhan formulasi yaitu 12,05 menit dan batas atas sebesar 14,55 menit. Untuk mencapai nilai waktu hancur sesuai dengan yang diprediksikan oleh program pada pengaplikasian produk Flakes harus menggunakan Tepung Ubi Cilembu $27,73 \%$ Tepung Tapioka $14,99 \%$, dan $12,29 \%$ Tepung Kacang Hijau.

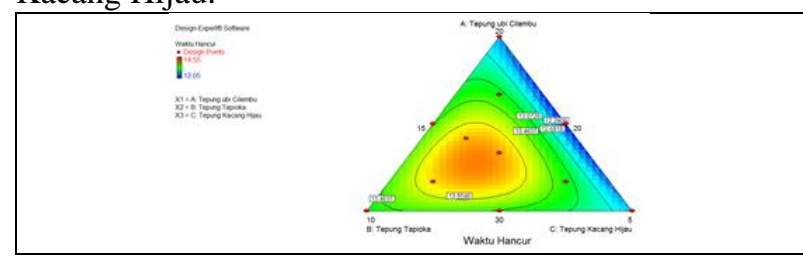

Gambar 6. Grafik Design Expert 11 Formulasi Berdasarkan Waktu Hancur

\section{Uji Organoleptik}

a. Warna Sebelum Penambahan Susu

Hasil analisis sidik ragam atau uji anova menunjukkan formula yang dibuat tidak berpengaruh nyata (probabilitas $>0.05$ ) terhadap waktu hancur yang diuji dengan selang kepercayaan 95\%. Analisis sidik ragam yang dilakukan oleh program Design Expert metode Mixture design d-optimal pada nilai respon organoleptik warna sebelum penambahan susu terhadap formula yang dibuat, menunjukkan model yang dibuat adalah tidak signifikan (probabilitas > 0.05), pada selang kepercayaan 95\% dengan nilai $\mathrm{p}=0,2752$. Artinya formula yang dibuat tidak berpengaruh nyata terhadap respon warna sebelum penambahan susu, sehingga nilai respon tersebut tidak dapat digunakan untuk proses optimasi yaitu untuk mendapatkan produk dengan karakteristik yang optimum.

Grafik di bawah menunjukkan formulasi optimal berdasarkan respon warna sebelum penambahan susu yang diprediksi oleh grafik ini sebesar 4,61\% dimana batas bawah warna sebelum penambahan susu dari keseluruhan formulasi yaitu 4,0\% dan batas atas sebesar $5,03 \%$. Untuk mencapai nilai warna sebelum penambahan susu sesuai dengan yang diprediksikan oleh program pada pengaplikasian produk Flakes harus menggunakan Tepung Ubi Cilembu 27,73\% Tepung Tapioka 14,99\%, dan 12,29\% Tepung Kacang Hijau.

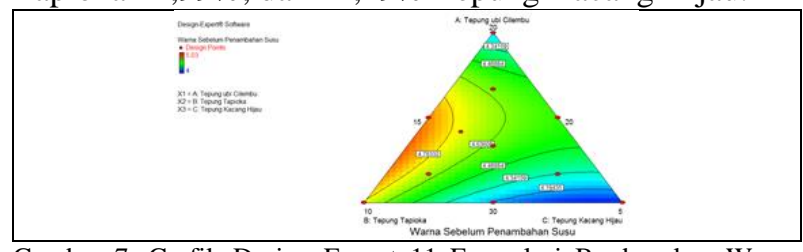

Gambar 7. Grafik Design Expert 11 Formulasi Berdasarkan Warna Sebelum Penambahan Susu

b. Warna Setelah Penambahan Susu
Hasil analisis sidik ragam atau uji anova menunjukkan formula yang dibuat tidak berpengaruh nyata (probabilitas > 0.05) terhadap waktu hancur yang diuji dengan selang kepercayaan 95\%. Analisis sidik ragam yang dilakukan oleh program Design Expert metode Mixture design d-optimal pada nilai respon organoleptik warna setelah penambahan susu terhadap formula yang dibuat, menunjukkan model yang dibuat adalah tidak signifikan (probabilitas > 0.05), pada selang kepercayaan 95\% dengan nilai $\mathrm{p}=0,2212$. Artinya formula yang dibuat tidak berpengaruh nyata terhadap respon warna setelah penambahan susu, sehingga nilai respon tersebut tidak dapat digunakan untuk proses optimasi yaitu untuk mendapatkan produk dengan karakteristik yang optimum.

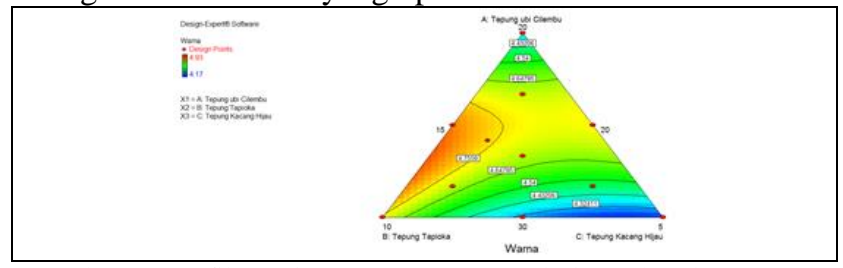

Gambar 8. Grafik Design Expert 11 Formulasi Berdasarkan Warna Setelah Penambahan Susu

Grafik di atas menunjukkan formulasi optimal berdasarkan respon warna setelah penambahan susu yang diprediksi oleh grafik ini sebesar 4,66\% dimana batas bawah warna setelah penambahan susu dari keseluruhan formulasi yaitu $4,17 \%$ dan batas atas sebesar $4,93 \%$. Untuk mencapai nilai warna setelah penambahan susu sesuai dengan yang diprediksikan oleh program pada pengaplikasian produk Flakes harus menggunakan Tepung Ubi Cilembu 27,73\% Tepung Tapioka 14,99\%, dan 12,29\% Tepung Kacang Hijau.

c. Rasa Setelah Penambahan Susu

Hasil analisis sidik ragam atau uji anova menunjukkan formula yang dibuat tidak berpengaruh nyata (probabilitas > 0.05) terhadap rasa setelah penambahan susu yang diuji dengan selang kepercayaan $95 \%$. Analisis sidik ragam yang dilakukan oleh program Design Expert metode Mixture design d-optimal pada nilai respon organoleptik rasa setelah penambahan susu terhadap formula yang dibuat, menunjukkan model yang dibuat adalah tidak signifikan (probabilitas > 0.05), pada selang kepercayaan $95 \%$ dengan nilai $\mathrm{p}=$ 0,2187 . Artinya formula yang dibuat tidak berpengaruh nyata terhadap respon rasa setelah penambahan susu, sehingga nilai respon tersebut tidak dapat digunakan untuk proses optimasi yaitu untuk mendapatkan produk dengan karakteristik yang optimum.

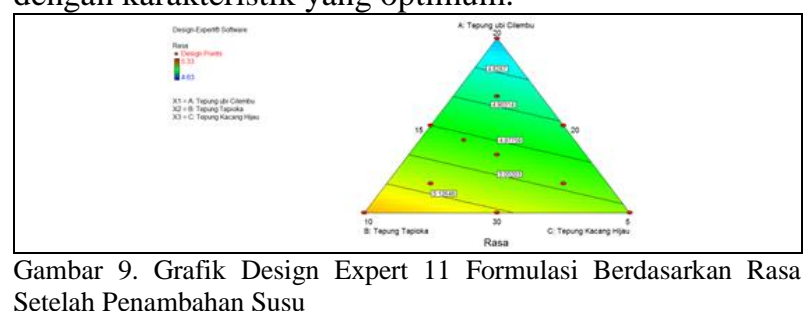


Grafik di atas menunjukkan formulasi optimal berdasarkan respon rasa setelah penambahan susu yang diprediksi oleh grafik ini sebesar 5,06\% dimana batas bawah rasa setelah penambahan susu dari keseluruhan formulasi yaitu 4,63\% dan batas atas sebesar 5,33\%. Untuk mencapai nilai rasa setelah penambahan susu sesuai dengan yang diprediksikan oleh program pada pengaplikasian produk Flakes harus menggunakan Tepung Ubi Cilembu 27,73\% Tepung Tapioka 14,99\%, dan 12,29\% Tepung Kacang Hijau.

\section{d. Aroma Setelah Penambahan Susu}

Hasil analisis sidik ragam atau uji anova menunjukkan formula yang dibuat berpengaruh nyata (probabilitas < 0.05) terhadap aroma setelah penambahan susu yang diuji dengan selang kepercayaan $95 \%$. Analisis sidik ragam yang dilakukan oleh program Design Expert metode Mixture design doptimal pada nilai respon organoleptik aroma setelah penambahan susu terhadap formula yang dibuat, menunjukkan model yang dibuat adalah signifikan (probabilitas < 0.05), pada selang kepercayaan 95\% dengan nilai $\mathrm{p}=0,0460$. Artinya formula yang dibuat berpengaruh nyata terhadap respon aroma setelah penambahan susu, sehingga nilai respon tersebut dapat digunakan untuk proses optimasi yaitu untuk mendapatkan produk dengan karakteristik yang optimum.

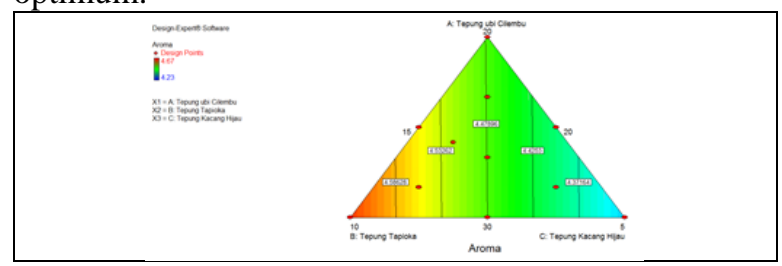

Gambar 10. Grafik Design Expert 11 Formulasi Berdasarkan Aroma Setelah Penambahan Susu

Grafik di atas menunjukkan formulasi optimal berdasarkan respon aroma setelah penambahan susu yang diprediksi oleh grafik ini sebesar 4,52\% dimana batas bawah aroma sebelum penambahan susu dari keseluruhan formulasi yaitu $4,23 \%$ dan batas atas sebesar 4,67\%. Untuk mencapai nilai aroma setelah penambahan susu sesuai dengan yang diprediksikan oleh program pada pengaplikasian produk Flakes harus menggunakan Tepung Ubi Cilembu 27,73\% Tepung Tapioka 14,99\%, dan 12,29\% Tepung Kacang Hijau.

\section{d. Kerenyahan Setelah Penambahan Susu}

Hasil analisis sidik ragam atau uji anova menunjukkan formula yang dibuat tidak berpengaruh nyata (probabilitas $>0.05$ ) terhadap kerenyahan setelah penambahan susu yang diuji dengan selang kepercayaan $95 \%$. Analisis sidik ragam yang dilakukan oleh program Design Expert metode Mixture design doptimal pada nilai respon organoleptik kerenyahan setelah penambahan susu terhadap formula yang dibuat, menunjukkan model yang dibuat adalah tidak signifikan (probabilitas > 0.05), pada selang kepercayaan 95\% dengan nilai $\mathrm{p}=0,4286$. Artinya formula yang dibuat tidak berpengaruh nyata terhadap respon kerenyahan setelah penambahan susu, sehingga nilai respon tersebut tidak dapat digunakan untuk proses optimasi yaitu untuk mendapatkan produk dengan karakteristik yang optimum.

Grafik di bawah menunjukkan formulasi optimal berdasarkan respon kerenyahan setelah penambahan susu yang diprediksi oleh grafik ini sebesar 4,79\% dimana batas bawah rasa sebelum penambahan susu dari keseluruhan formulasi yaitu $4,47 \%$ dan batas atas sebesar 5,9\%. Untuk mencapai nilai kerenyahan setelah penambahan susu sesuai dengan yang diprediksikan oleh program pada pengaplikasian produk Flakes harus menggunakan Tepung Ubi Cilembu 26,54\% Tepung Tapioka $16,31 \%$, dan $12,14 \%$ Tepung Kacang Hijau.

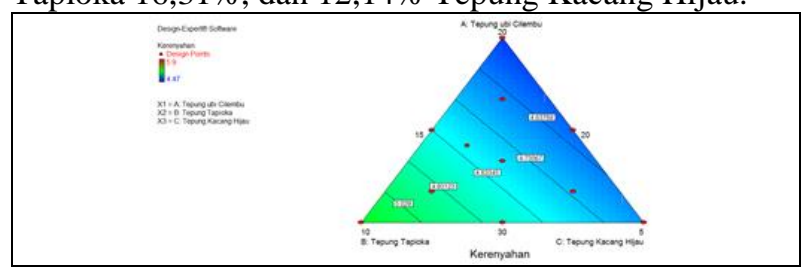

Gambar 11. Grafik Design Expert 11 Formulasi Berdasarkan Kerenyahan Setelah Penambahan Susu

\section{Uji Formulasi Terpilih}

Formulasi terpilih merupakan solusi atau formulasi optimal yang diprediksikan oleh design expert metode mixture design d-optimal berdasarkan analisis terhadap respon kimia (kadar protein, kadar lemak, kadar serat kasar, dan kadar air), respon fisik (daya serap air, waktu hancur), dan respon organoleptik (warna sebelum penambahan susu, warna setelah penambahan susu, rasa setelah penambahan susu, aroma setelah penambahan susu, dan kerenyahan setelah penambahan susu).

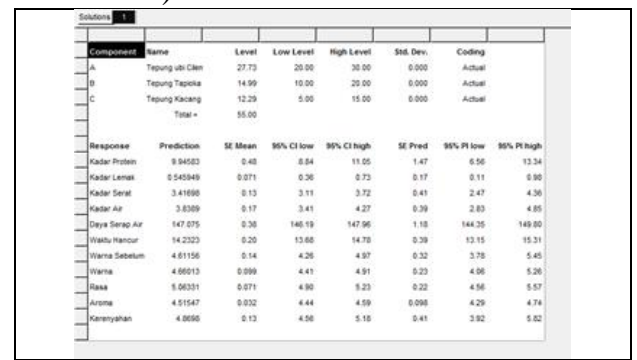

Gambar 12. Formulasi Flakes (Tepung Ubi Cilembu, Tepung Tapioka, dan Tepung Kacang Hijau) Terbaik

Ketepatan formulasi dan nilai masing-masing respon tersebut dapat dilihat pada desirability. Desirability adalah derajat ketepatan hasil solusi atau formulasi optimal. Semakin mendekati nilai satu maka semakin tinggi keteatan formulasi, sehingga dapat disimpulkan berdasarkan nilai desirability yang telah mencapai 1,00 maka formulasi yang dihasilkan memiliki nilai ketepatan yang tinggi.

Berdasarkan desirability diatas formulasi optimal Flakes diperoleh 1 formulasi yang ditawarkan dimana memiliki jumlah presentase tersebut yaitu Tepung Ubi Cilembu 27,73\% Tepung Tapioka 14,99\%, dan 12,29\% 
Tepung Kacang Hijau. Formula tersebut diprediksikan oleh program dengan kadar protein 9,95\%; kadar lemak 0,55\%; kadar serat kasar 3,42\%; kadar air 3,84\%; daya serap air 147,08\%; waktu hancur 14,23 menit; warna sebelum penambahan susu 4,61; warna setelah penambahan susu 4,66; rasa setelah penambahan susu 5,06; aroma setelah penambahan susu 4,52; dan kerenyahan setelah penambahan susu 4,87.

Tabel 3. Perbandingan Hasil Analisis Design Expert Metode Mixture Design D-optimal dengan Analisis Laboratorium dan Uji organoleptik terhadap Flakes Formula Terpilih

\begin{tabular}{|c|c|c|}
\hline Senyawa & Aplikasi & Laboratorium \\
\hline Protein (\%) & 9,95 & 8,87 \\
\hline Lemak (\%) & 0,55 & 0,38 \\
\hline Serat Kasar (\%) & 3,42 & 3,96 \\
\hline Air (\%) & 3,84 & 3,5 \\
\hline $\begin{array}{c}\text { Daya Serap Air } \\
(\%)\end{array}$ & 147,08 & 141,03 \\
\hline $\begin{array}{c}\text { Waktu Hancur } \\
\text { (menit) }\end{array}$ & 14,23 & 15 \\
\hline Warna (1) & 4,61 & 4,7 \\
\hline Warna (2) & 4,66 & 5,33 \\
\hline Rasa (2) & 5,06 & 5,47 \\
\hline Aroma (2) & 4,52 & 5,27 \\
\hline Kerenyahan (2) & 4,87 & 4,57 \\
\hline
\end{tabular}

Keterangan :

(1) Sebelum Penambahan Susu

(2) Setelah Penambahan Susu

Perbandingan hasil program dengan analisis laboratorium dan uji organoleptik untuk mengukur nilai desirability yang dihasilkan oleh program yang memiliki nilai ketepatan 1 yang berarti sangat tepat. Berdasarkan data yang dihasilkan selisih hasil dari keduanya tidak berbeda terlalu jauh.

\section{Kadar Protein}

Warna menunjukkan nilai yang diperoleh terhadap respon. Semakin tinggi nilai kadar protein warna yang dihasilkan menunjukkan warna merah, sedangkan semakin rendah nilai kadar protein warna yang dihasilkan menunjukkan warna biru. Prediksi kadar protein pada formulasi terpilih adalah 9,95\%, daerah yang menunjukkan prediksi kadar protein berada pada warna hijau yang artinya prediksi berada pada pertengahan batas atas dan batas bawah nilai kadar protein.

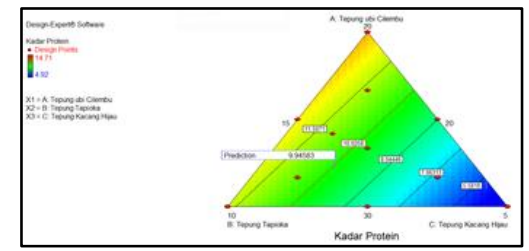

Gambar 13. Gambar 29. Grafik Prediksi Design Expert Kadar Protein Formulasi Optimal Flakes (Tepung Ubi Cilembu, Tepung Tapioka, dan Tepung Kacang Hijau)

2. Kadar Lemak

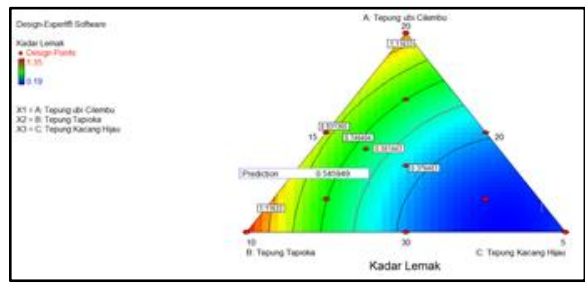

Gambar 14. Grafik Prediksi Design Expert Kadar Lemak Formulasi Optimal Flakes (Tepung Ubi Cilembu, Tepung Tapioka, dan Tepung Kacang Hijau)

Warna menunjukkan nilai yang diperoleh terhadap respon. Semakin tinggi nilai kadar lemak warna yang dihasilkan menunjukkan warna merah, sedangkan semakin rendah nilai kadar lemak warna yang dihasilkan menunjukkan warna biru. Prediksi kadar lemak pada formulasi terpilih adalah 0,55\%, daerah yang menunjukkan prediksi kadar lemak berada pada warna biru muda yang artinya prediksi mendekati batas bawah nilai kadar lemak.

\section{Kadar Serat Kasar}

Warna menunjukkan nilai yang diperoleh terhadap respon. Semakin tinggi nilai kadar serat kasar warna yang dihasilkan menunjukkan warna merah, sedangkan semakin rendah nilai kadar serat kasar warna yang dihasilkan menunjukkan warna biru. Prediksi kadar serat kasar pada formulasi terpilih adalah 3,42\%, daerah yang menunjukkan prediksi kadar serat kasar berada pada warna hijau mendekati kuning yang artinya prediksi mendekati batas atas nilai kadar serat kasar.

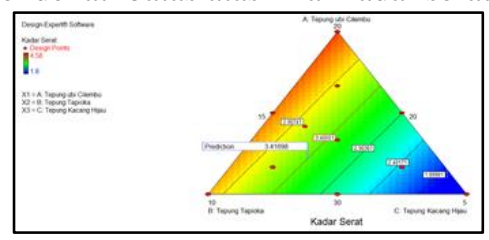

Gambar 15. Grafik Prediksi Design Expert Kadar Serat Kasar Formulasi Optimal Flakes (Tepung Ubi Cilembu, Tepung Tapioka, dan Tepung Kacang Hijau)

\section{Kadar Air}

Warna menunjukkan nilai yang diperoleh terhadap respon. Semakin tinggi nilai kadar air warna yang dihasilkan menunjukkan warna merah, sedangkan semakin rendah nilai kadar air warna yang dihasilkan menunjukkan warna biru. Prediksi kadar air pada formulasi terpilih adalah 3,84\%, daerah yang menunjukkan prediksi kadar air berada pada warna kuning yang artinya prediksi mendekati batas atas nilai kadar air. 


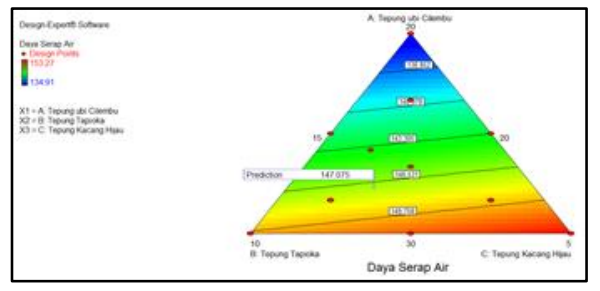

Gambar 16. Grafik Prediksi Design Expert Kadar Air Formulasi Optimal Flakes (Tepung Ubi Cilembu, Tepung Tapioka, dan Tepung Kacang Hijau)

\section{Daya Serap Air}

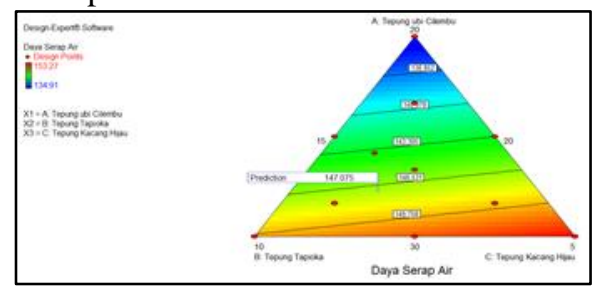

Gambar 17. Grafik Prediksi Design Expert Daya Serap Air Formulasi Optimal Flakes (Tepung Ubi Cilembu, Tepung Tapioka, dan Tepung Kacang Hijau)

Warna menunjukkan nilai yang diperoleh terhadap respon. Semakin tinggi nilai daya serap air warna yang dihasilkan menunjukkan warna merah, sedangkan semakin rendah nilai daya serap air warna yang dihasilkan menunjukkan warna biru. Prediksi daya serap air pada formulasi terpilih adalah 146,08\%, daerah yang menunjukkan prediksi daya serap air berada pada warna hijau mendekati warna kuning yang artinya prediksi mendekati batas atas nilai daya serap air.

\section{Waktu Hancur}

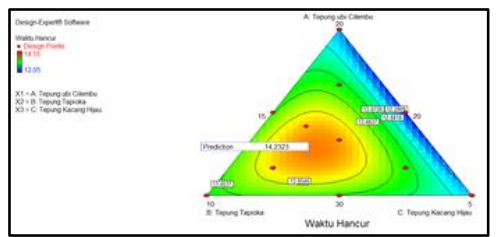

Gambar 18. Grafik Prediksi Design Expert Waktu Hancur Formulasi Optimal Flakes (Tepung Ubi Cilembu, Tepung Tapioka, dan Tepung Kacang Hijau)

Warna menunjukkan nilai yang diperoleh terhadap respon. Semakin tinggi nilai waktu hancur warna yang dihasilkan menunjukkan warna merah, sedangkan semakin rendah nilai waktu hancur warna yang dihasilkan menunjukkan warna biru. Prediksi waktu hancur pada formulasi terpilih adalah 14,23 menit, daerah yang menunjukkan prediksi waktu hancur berada pada warna jingga yang artinya prediksi mendekati batas atas nilai waktu hancur.

\section{Uji Organoleptik}

a. Warna Sebelum Penambahan Susu

Warna menunjukkan nilai yang diperoleh terhadap respon. Semakin tinggi nilai organoleptik warna sebelum penambahan susu warna yang dihasilkan menunjukkan warna merah, sedangkan semakin rendah nilai organoleptik warna sebelum penambahan susu warna yang dihasilkan menunjukkan warna biru.
Prediksi warna sebelum penambahan susu pada formulasi terpilih adalah 4,61, daerah yang menunjukkan prediksi warna sebelum penambahan susu berada pada warna hijau yang artinya prediksi berada pada pertengahan batas atas dan batas bawah nilai warna sebelum penambahan susu.

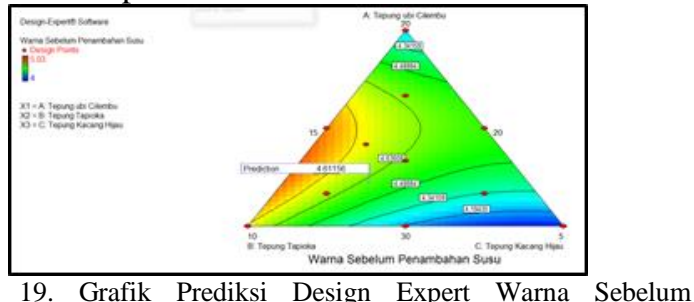

Gambar 19. Grafik Prediksi Design Expert Warna Sebelum Penambahan Susu Formulasi Optimal Flakes (Tepung Ubi Cilembu, Tepung Tapioka, dan Tepung Kacang Hijau)

b. Warna Setelah Penambahan Susu

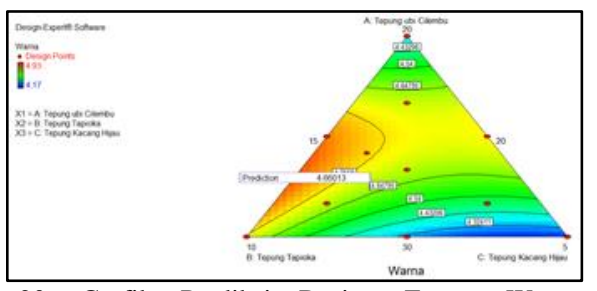

Gambar 20. Grafik Prediksi Design Expert Warna Setelah Penambahan Susu Formulasi Optimal Flakes (Tepung Ubi Cilembu, Tepung Tapioka, dan Tepung Kacang Hijau)

Warna menunjukkan nilai yang diperoleh terhadap respon. Semakin tinggi nilai organoleptik warna setelah penambahan susu warna yang dihasilkan menunjukkan warna merah, sedangkan semakin rendah nilai organoleptik warna setelah penambahan susu warna yang dihasilkan menunjukkan warna biru. Prediksi warna setelah penambahan susu pada formulasi terpilih adalah 4,66, daerah yang menunjukkan prediksi warna setelah penambahan susu berada pada warna hijau mendekati kuning yang artinya prediksi berada pada pertengahan batas atas dan batas bawah nilai warna setelah penambahan susu.

c. Rasa Setelah Penambahan Susu

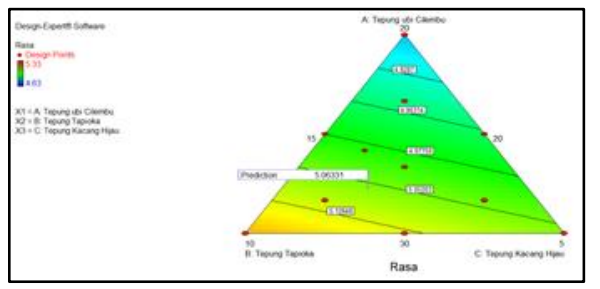

Gambar 21. Grafik Prediksi Design Expert Rasa Setelah Penambahan Susu Formulasi Optimal Flakes (Tepung Ubi Cilembu, Tepung Tapioka, dan Tepung Kacang Hijau)

Warna menunjukkan nilai yang diperoleh terhadap respon. Semakin tinggi nilai organoleptik rasa setelah penambahan susu warna yang dihasilkan menunjukkan warna merah, sedangkan semakin rendah nilai organoleptik rasa setelah penambahan susu warna yang dihasilkan menunjukkan warna biru. Prediksi rasa setelah penambahan susu pada formulasi terpilih adalah 5,06, daerah yang menunjukkan prediksi rasa setelah 
penambahan susu berada pada warna hijau yang artinya prediksi berada pada pertengahan batas atas dan batas bawah nilai rasa setelah penambahan susu.

\section{d. Aroma Setelah Penambahan Susu}

Warna menunjukkan nilai yang diperoleh terhadap respon. Semakin tinggi nilai organoleptik aroma setelah penambahan susu warna yang dihasilkan menunjukkan warna merah, sedangkan semakin rendah nilai organoleptik aroma setelah penambahan susu warna yang dihasilkan menunjukkan warna biru. Prediksi aroma setelah penambahan susu pada formulasi terpilih adalah 4,52, daerah yang menunjukkan prediksi aroma setelah penambahan susu berada pada warna kuning yang artinya prediksi mendekati batas atas nilai bawah nilai aroma setelah penambahan susu.

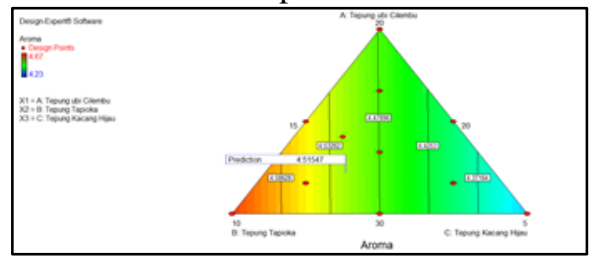

Gambar 22. Grafik Prediksi Design Expert Aroma Setelah Penambahan Susu Formulasi Optimal Flakes (Tepung Ubi Cilembu, Tepung Tapioka, dan Tepung Kacang Hijau)

e. Kerenyahan Setelah Penambahan Susu

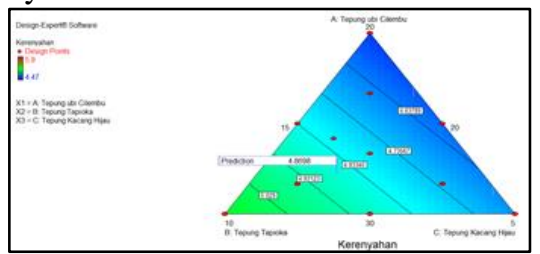

Gambar 23. Grafik Prediksi Design Expert Kerenyahan Setelah Penambahan Susu Formulasi Optimal Flakes (Tepung Ubi Cilembu, Tepung Tapioka, dan Tepung Kacang Hijau)

Warna menunjukkan nilai yang diperoleh terhadap respon. Semakin tinggi nilai organoleptik kerenyahan setelah penambahan susu warna yang dihasilkan menunjukkan warna merah, sedangkan semakin rendah nilai organoleptik kerenyahan setelah penambahan susu warna yang dihasilkan menunjukkan warna biru. Prediksi kerenyahan setelah penambahan susu pada formulasi terpilih adalah 4,87 , daerah yang menunjukkan prediksi kerenyahan setelah penambahan susu berada pada warna biru muda yang artinya prediksi mendekati batas bawah nilai bawah nilai kerenyahan setelah penambahan susu.

\section{Nilai Kalori}

Hasil kecukupan kalori pada flakes berbasis (tepung ubi Cilembu, tepung tapioka, tepung kacang hijau) pada formulasi optimal yang diteliti sebesar $342,34 \mathrm{kkal}$.

Berdasarkan hasil penelitian, dapat disimpulkan bahwa formulasi optimal yang diprediksi oleh program Design Expert metode mixture d-optimal terhadap respon kimia yaitu memiliki respon kadar protein 9,95\%; kadar lemak 0,55\%; kadar serat 3,42\%; respon fisik yaitu kadar air 3,84\%; daya serap air 147,08\%; waktu hancur 14,23 menit, serta respon organoleptik yaitu warna sebelum penambahan susu 4,61; warna setelah penambahan susu 4,66; rasa setelah penambahan susu 5,06; aroma setelah penambahan susu 4,52; kerenyahan setelah penambahan susu 4,87.

Hasil analisis laboratorium mendekati prediksi program Design Expert metode Mixture D-optimal, dimana hasil analisis laboratorium formulasi optimal terhadap kadar protein 8,87\%; kadar lemak 0,55\%; kadar serat 3,42\%; kadar air 3,84\%; daya serap air 147,08\%; waktu hancur 15 menit; warna sebelum penambahan susu 4,61; warna setelah penambahan susu 4,66, rasa setelah penambahan susu 5,06; aroma setelah penambahan susu 4,52; kerenyahan setelah penambahan susu 4,87. Kalori yang dihasilkan oleh Flakes berbasis tepung ubi Cilembu, tepung tapioka, dan tepung kacang hijau sebesar 342,34 kkal.

\section{Daftar Pustaka}

1. Aini, Nurly Qurrota., dan Yekti Wirawan., 2013. Kontribusi Mp-Asi Biskuit Substitusi Tepung Garut, Kedelai, dan Ubi Jalar Kuning Terhadap Kecukupan Protein, Vitamin A, Kasium dan Zink Pada Bayi. Fakultas Kedokteran. Universitas Diponogoro. Semarang.

2. Aryanti, 2012. Karakteristika Mutan Tepung Ubi Jalar. Pusat Aplikasi Teknologi Isotop dan Radiasi.Batan.

3. Astawan, Made., 2009. Sehat dengan Hidangan Kacang dan Biji-bijian. Penebar Swadaya. Jakarta.

4. Badan Pusat Statistik, 2015. Luas Panen Kacang Hijau Menurut Provinsi. Badan Pusat Statistik. Jakarta Pusat.

5. Badan Pusat Statistik, 2015. Luas Panen Ubi Jalar Menurut Provinsi. Badan Pusat Statistik. Jakarta Pusat.

6. Badan Pusat Statistik, 2015. Produksi Kacang Hijau Menurut Provinsi. Badan Pusat Statistik. Jakarta Pusat.

7. Badan Pusat Statistik, 2015. Produksi Ubi Jalar Menurut Provinsi. Badan Pusat Statistik. Jakarta Pusat.

8. Badan Pusat Statistik, 2015. Produktivitas Kacang Hijau Menurut Provinsi. Badan Pusat Statistik. Jakarta Pusat.

9. Badan Pusat Statistik, 2015. Produktivitas Ubi Jalar Menurut Provinsi. Badan Pusat Statistik. Jakarta Pusat.

10. Buckle, K.A., Edwards, R.A., Fleet,G.H. dan Woonton,M., 1987. Ilmu Pangan.Universitas Indonesia Press. Jakarta.

11. Burhanuddin. 2001. Strategi Pengembangan Industri Garam di Indonesia.Kanisius, Yogyakarta.

12. Chairil, M. Mifthah Faridh., dan Lilik Kustiyah. 2014. Formulasi Flakes Berbasis Pati Garut Dengan Fortifikasi Zat Besi (Fe) Untuk Perbaikan Status 
Besi Remaja Putri.Jurnal Gizi dan Pangan. Departemen Gizi Masyarakat. Fakultas Ekologi Manusia. Institut Pertanian Bogor. Bogor.

13. Gisca I.D, Bernadheta., dan Arintina Rahayuni., 2013. Penambahan Gembili Pada Flakes Jewawut Ikan Gabus Sebagai Alternatif Makanan Tambahan Anak Gizi Kurang. Program Studi Ilmu Gizi. Fakultas Kedokteran. Universitas Diponegoro. Semarang..

14. Juanda JS, Dede., dan Bambang Cahyono. 2000. Ubi Jalar Budi Daya dan Analisis Usaha Tani.Penerbit Kanisius.Yogyakarta.

15. Kartika, B., Hastuti, P dan Supartono, W. 1988. Pedoman Uji Inderawi Bahan Pangan. Pusat Antar Universitas Pangan dan Gizi. Yogyakarta.

16. Ketra, Anton Ramadhan., dan Okta Wulandra. 2015. Substitusi Ubi Jalar Dalam Pembuatan Bolu Gulung. Jurnal Agritepa Vol. 1 No. 2. Fakultas Pertanian. Universitas Dehasen. Bengkulu.

17. Kurniawati, Indra., dan Endang Murniati., 2013. Controlled Deterioration Test untuk Menguji Ketahanan Benih Kacang Hijau (Phaseolus radiatus L.) terhadap Kondisi Cekaman Kekeringan.Departemen Agronomi dan Hortikultura. Fakultas Pertanian. Institut Pertanian Bogor. Bogor.

18. Muchtadi, Tien., dan Sugiyono., 2013. Ilmu Pengetahuan Bahan Pangan. CV. Alfabeta. Bandung.

19. Nurhayati, Dwi Putri., 2016. Optimalisasi Edam Cheese, Natural Cheddar Cheese Isolat Soy Protein Terhadap Spreadable Cheese Analogue Menggunakan Aplikasi Design Expert (Mixture Design). Program Studi Teknnologi pangan. Fakultas Teknik. Universitas Pasundan. Bandung.

20. Papunas, Meini Ekawati., Gregoria S. S. Djarkasi., dan Judith S. C, Moningka., 2013. Karakteristik Fisikokimia Dan Sensoris Flakes Berbahan Baku Tepung Jagung (Zea mays L), Tepung Pisang Goroho (Musa acuminafe,sp) dan Tepung Kacang Hijau (Phaseolus radiates). Program Studi Ilmu dan Teknologi Pangan Unsrat. Teknologi Pangan. Universitas Sam Ratulangi. Sulawesi Utara.

21. Paramita, Anggi Hapsari., dan Widya Dwi Rukmi Putri., 2015. Pengaruh Penambahan Tepung Bengkuang Dan Lama Pengukusan Terhadap Karakteristik Fisik, Kimia dan Organoleptik Flakes Talas.Jurnal Pangan dan Agroindustri Vol. 3 No 3.Jurusan Teknologi Hasil Pertanian. Fakultas Teknologi Pertanian. Universitas Brawijaya. Malang.

22. Permana, Rikhardo Atmaka., dan Widya Dwi Rukmi Putri. 2015. Pengaruh Proporsi Tepung Jagung dan Kacang Merah Serta Substitusi Bekatul Terhadap Karakteristik Fisik Kimia Flakes.Jurnal Pangan dan Agroindustri Vol. 3 No 2.Jurusan Teknologi Hasil Pertanian. Fakultas Teknologi Pertanian. Universitas Brawijaya. Malang.
23. Pratiwi, Karina Widya. 2016. Formulasi Tepung Ubi Jalar Cilembu (Ipomoea batatas (L.) dan Tepung Jagung (Zea Mays) Terfermentasi Terhadap Sifat Kimia dan Sensori Flakes. Fakultas Pertanian. Universitas Lampung. Bandar Lampung.

24. Purnamasari, Ika Wind., dan Widya Dwi Rukmi Putri. 2015. Pengaruh Penambahan Tepung Labu Kuning dan Natrium Bikarbonat Terhadap Karakteristik Flakes Talas.JurnalPangan dan Agroindustri Vol. 3 No 4.Jurusan Teknologi Hasil Pertanian. Fakultas Teknologi Pertanian. Universitas Brawijaya. Malang.

25. Purwono., dan Heni Purnamawati., 2007. Budidaya 8 Jenis Tanaman Pangan Unggul. Penebar Swadaya. Jakarta.

26. Purwono., dan Rudi Hartono., 2005. Kacang Hijau. Penebar Swadaya. Jakarta.

27. Rakhmawati, Novia., Bambang Sigit Amanto., dan Danar Praseptiangga., 2014. Formulasi dan Evaluasi Sifat Sensoris dan Fisikokimia Produk Flakes komposit Berbahan Dasar Tepung Tapioka, Tepung Kacang Merah (Phaseolus vulgaris L.)dan Tepung Konjac (Amorphophallus oncophillus).Jurnal Teknologi Pangan Vol.3 No.1.Jurusan Teknologi Hasil Pertanian. Fakultas Pertanian. Universitas Sebelas Maret.

28. Sahid, Susanti Citra., 2015. Optimasi Dendeng Jamur Tiram Putih (Pleurotus Ostreatus) Dengan Menggunakan Design Expert Metoda D-Optimal. Program Studi Teknologi Pangan. Fakultas Teknik. Universitas Pasundan. Bandung.

29. Setiaji, Bayu. 2012. Pengaruh Suhu dan Lama Pemannggangan Terhadap Karakteristik Soy Flakes (Glycine max L).Program Studi Teknnologi pangan. Fakultas Teknik. Universitas Pasundan. Bandung.

30. Sianturi, Daniel Pratama., dan Sri Anna Marliyati., 2014. Formulasi Flakes Tepung Komposit Pati Garut dan Tepung Singkong Dengan Penambahan Pegagan Sebagai Pangan Fungsional Sarapan Anak Sekolah Dasar. Departemen Gizi Masyarakat.Fakultas Ekologi Manusia.Institut Pertanian Bogor.Bogor.

31. Sukerti,Ni Wayan., Damiati, Cok Istri Raka Marsiti, NDMSAdnyawati,. 2013. Pengaruh Modifikasi Tiga Varietas Tepung Ubi Jalar dan Terigu Terhadap Kualitas dan Daya Terma Mi Kering. Jurusan Pendidikan Kesejahteraan Keluarga. Fakultas Teknik dan Kejuruan. Universitas Pendidikan Ganesh. Singaraja.

32. Suprapti, Lies., 2005. Tepung Tapioka Pembuatan dan Pemanfaatannya. Penerbit Kasinius. Yogyakarta.

33. Widyasitoresmi, Helena Suri. 2010. Formulasi Dan Karakterisasi Flakes Berbasis Sorgum (Sorghum bicolor L.) dan Ubi Jalar Ungu (Ipomoea batatas L.). Fakultas Teknologi Pertanian. Institut Pertanian Bogor. Bogor. 
34. Wijaya, Yesicca dan Widya Dwi Rukmi. 2015. Karakterisasi Beras Tiruan Berbahan Baku Tepung Ubi Jalar Oranye (Ipomoea batatas L.var Ase Jantan) Hasil Modifikasi (Sodium Tripolyphospate). Jurnal Pangan dan Agroindustri Vol. 3 No 1.Jurusan Teknologi Hasil Pertanian.Fakultas Teknologi Pertanian. Universitas Brawijaya. Malang.

35. Wijayanti, Sudarma Dita., Tri Dewanti., Widyaningsih., dan Dzulvina Utami., 2015. Evaluasi Nilai Cerna In Vitro Sereal Flake berbasis Ubi Jalar Oranye Tersuplementasi Kecambah Kacang Tunggak. Jurnal Teknologi Pertanian Vol. 16 No. 1 . Jurusan Teknologi Hasil Pertanian. Fakultas Teknologi Pertanian . Universitas Brawijaya.

36. Winarno, F.G. 2004.Kimia Pangan dan Gizi.PT Gramedia Pustaka Utama. Jakarta.

37. Zebua, Silwanus J., dan Rohmanti Rabaniah., 2012. Benih Kacang Hijau (Vigna radiata (L.) R. Wilczek) Pada Pertamanan Monokultur dan Tumpang Sari Dengan Jagung (Zea mays L.). Fakultas Pertanian. Universitas Gadjah Mada. Yogyakarta.

38. Zulhanifah S, Mutiani, 2015. Pengaruh Perbandingan Tepung Biji Koro Pedang Dengan Tepung tempe Kacang Koro Pedang (Canavalia ensiformis L) Terhadap Karakteristik Flakes. Program Studi Teknnologi pangan. Fakultas Teknik. Universitas Pasundan. Bandung. 